\title{
ANALYSIS OF IL-6, IL-10 AND NF-KB GENE POLYMORPHISMS IN AGGRESSIVE AND CHRONIC PERIODONTITIS
}

\author{
Hülya Toker ${ }^{1}$, Emine Pirim Görgün ${ }^{1}$, Ertan Mahir Korkmaz ${ }^{2}$ \\ 'Department of Periodontology, Faculty of Dentistry, Cumhuriyet University, Sivas, Turkey \\ ${ }^{2}$ Department of Molecular Biology and Genetics, Faculty of Science, Cumhuriyet University, Sivas, Turkey
}

\section{SUMMARY}

Objective: Pro-inflammatory cytokines, interleukin-6 (IL-6), demonstrated to be suppressed by interleukin-10 (IL-10) are known to be regulated by the transcription factor nuclear factor- $\mathrm{KB}(\mathrm{NF}-\mathrm{KB})$. The aim of this study was to ascertain the association between genetic polymorphism of these genes (IL-6(-174), IL-10(-597) and NF-kB1-94ins/del)) and chronic/aggressive periodontitis.

Methods: Forty-five patients with chronic periodontitis (CP), 58 patients with aggressive periodontitis (AP) and 38 periodontally healthy subjects were included in this study. Genomic DNA was isolated from whole blood samples. The NF-KB, IL-6, and IL-10 polymorphisms were determined by the polymerase chain reaction-restriction fragment length polymorphism (PCR-RFLP) method.

Results: Among subjects for the ins/ins genotypes of NF-KB1 gene, the AA genotypes of IL-10 presented a higher frequency in chronic periodontitis group than in healthy controls $(p=0.023)$. A statistically significant difference in genotyping frequencies between AP group and healthy controls was observed for the IL-6 gene. The AA genotype of IL-10 was overrepresented in CP and AP groups compared to healthy controls (OR=9.93, 95\% Cl: $2.11-46.7, \mathrm{OR}=5.7,95 \% \mathrm{Cl}: 1.22-26.89$, respectively).

Conclusions: Within the limits of this study, it can be concluded that the IL-10 (-597) AA genotype is associated with susceptibility to chronic/ aggressive periodontitis and IL-6 (-174) GG genotypes and $\mathrm{G}$ allele seems to be associated with aggressive periodontitis.

Clinical relevance: The results of the current study indicate that IL- 6 and IL-10 genotypes seem to be associated with aggressive periodontitis. Also, the AA genotypes of IL-10 presented a higher frequency in chronic periodontitis subjects with carrying NF-KB1 ins/ins genotypes.

Key words: periodontitis, polymorphism, NF-KB, L-6, IL-10

Address for correspondence: E. P. Görgün, Department of Periodontology, Cumhuriyet University Faculty of Dentistry, Sivas 58140, Turkey. E-mail: eminepirim09@hotmail.com

https://doi.org/10.21101/cejph.a4656

\section{INTRODUCTION}

Periodontitis is an inflammatory disease associated with a bacterial infection. Immune response of the periodontal tissues to infection is influenced by environmental factors as well as genetic factors (1). The complex cytokine network that mediates the immune response includes pro-inflammatory cytokines, antiinflammatory cytokines and specific cytokine receptors. Furthermore, genetic variants of some cytokines confer susceptibility to periodontitis (2-4).

Nuclear factor- $\mathrm{KB}$ (NF- $\mathrm{kB}$ ) is a transcription factor that is involved in inflammation, cell survival, angiogenesis and apoptosis (5). Five members of the NF- $\mathrm{BB}$ family have been identified, and

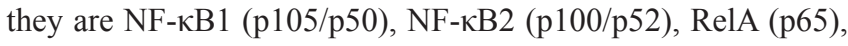
RelB and c-Rel. Several polymorphisms have been identified in the promoter region of NF-kB1 gene, which is insertion/deletion (-94ins/delATTG) (6). However, one study conducted on periodontal disease reported that del/del genotype of NF-kB1 gene was associated with aggressive periodontitis (7). NF- $\mathrm{kB}$ is highly activated at sites of inflammation and can induce transcription of pro-inflammatory cytokines (TNF- $\alpha$, IL-1 $\beta$, IL-6 and IL-8), chemokines, adhesion molecules, and matrix metalloproteinases (8). Also, some cytokines can directly activate NF-kB pathway, thus establishing a positive auto-regulatory loop that can amplify the inflammatory response and increase the duration of chronic inflammation. However, NF-kB, can act as an anti-inflammatory factor and has a role in IL-10 gene expression (9).

Among several kinds of cytokines, IL-6 has been shown to increase in the gingival crevicular fluids and in the gingival tissues of individuals with periodontitis (10). IL-6 is also a potent stimulator of osteoclast differentiation and bone resorption and an inhibitor of bone formation (2). In the IL-6 gene, there are more than four known promoter polymorphisms: -597 (G/A), -572 (C/G), -174 (G/C) single nucleotide polymorphisms, and -373 AnTm polymorphisms (11). As the $-174 \mathrm{G} / \mathrm{C}$ and $-572 \mathrm{C} / \mathrm{G}$ polymorphisms of the IL-6 gene increase IL-6 expression, they may be associated with susceptibility to periodontitis $(2,12,13)$. However, the frequency of many genetic alleles varies among ethnic groups, several studies have found contradictory results regarding the relationship between this gene and periodontitis $(2,10,14)$. 
IL-10, an anti-inflammatory cytokine, plays a role in periodontitis by inhibiting synthesis of pro-inflammatory cytokines such as IL-1, -2, -6 and stimulating protective antibody production (15). The gene encoding for IL-10 is mapped on chromosome one (1q31-32) (16). A large number of single nucleotide polymorphisms have been identified in the IL-10 gene promoter (17). Of interest are the polymorphisms at -1082 (-1087), -819 (-824) and $-592(-597)(18)$. However, the presence of an association between IL-10 gene polymorphisms and clinical manifestations of chronic and aggressive periodontitis is controversial. Some of the studies failed to find any evidence of association $(4,19,20)$ and others revealed a possible association between this polymorphism and periodontitis $(17,21-24)$. Considering the multifactorial nature of a periodontal disease, little is known among the complex interaction of the polymorphisms in the promoter regions of IL-6 (-174), IL-10 (-597) and NF-кB1 (-94ins/del) genes and clinical parameters of periodontitis. Therefore, we carried out a clinical study to assess the effect of these polymorphisms in chronic and aggressive periodontitis and to evaluate associations among the polymorphisms themselves.

\section{MATERIALS AND METHODS}

\section{Study Population}

The study had a case-control design. This study presented the gene polymorphisms part of collected data at approved studies by the Medical Ethics Committee of Cumhuriyet University (2011/031 and 2012-02/35). All subjects signed a consent form. A total of 141 subjects, including 45 with chronic periodontitis, 58 with aggressive periodontitis, and 38 periodontally healthy individuals were selected for the study from the Department of Periodontology, Faculty of Dentistry, Cumhuriyet University. All subjects were Turkish Caucasian and have low to moderate socioeconomic status. Excluding criteria were diseases of oral soft and hard tissues in oral cavity, excluding caries and periodontitis; presence of orthodontic apparatuses in mouth; usage of systemic antibiotics in period of three months before engagement in this study; pregnancy and lactation; diabetes; appliance of immunesuppressive therapy; and current or former smokers.

The diagnosis of subjects was established on the basis of clinical and radiographic criteria proposed by the 1999 International World Workshop for a Classification of Periodontal Diseases and Conditions (25).

\section{Generalized Chronic Periodontitis Group}

The generalized chronic periodontitis group consisted of 45 subjects. The diagnosis of chronic periodontitis was assigned to patients when they demonstrated clinical attachment levels (CAL) in at least $30 \%$ of their teeth (CAL $\geq 5 \mathrm{~mm}$ ) with pocket depth $>5 \mathrm{~mm}$.

\section{Generalized Aggressive Periodontitis Group}

The generalized aggressive periodontitis group consisted of 58 subjects with a history of rapid attachment loss and bone destruction. The diagnosis of aggressive periodontitis was assigned to patients when they demonstrated pocket depth (PD) and CAL $\geq 5 \mathrm{~mm}$ and radiographic bone loss of $\geq 30 \%$ of root length on at least three teeth other than first molars or incisors. In addition, patients were not included if it was assumed that periodontal destruction was caused by local risk factors like poor restorations and poor oral hygiene.

\section{Healthy Control Group}

Control subjects were designated as healthy if they had full mouth probing pocket depth less than $3 \mathrm{~mm}$, gingival index scores equal to 0 and there was no radiographic evidence of alveolar bone loss. These individuals were systemically and periodontally healthy volunteers.

\section{Clinical Measurements}

A clinical examination was performed by one calibrated examiner (E.P.G.). Full-mouth measures of probing pocket depth (PD), clinical attachment levels (CAL) were obtained at six points per tooth. The presence of supragingival plaque was scored using plaque index (PI) (26). Gingival inflammation was scored using gingival index (GI) (26). Bleeding on probing (BOP) was also recorded. PD and CAL measures were obtained using a Williams' periodontal probe.

\section{DNA Extraction and Genotyping}

From each patient, we collected $2 \mathrm{ml}$ of blood from the antecubital vein. The blood samples were collected in sodium EDTA vacutainers, and stored at $-80^{\circ} \mathrm{C}$ until genetic analyses were performed. The extraction of DNA was performed with a commercial kit (Invitrogen, Cambrillo, USA) following the manufacturer's protocol.

Each sample of DNA was analyzed for polymorphisms in the IL-6 gene at position -174, in the IL-10 gene at position -597 and in the NF- $\kappa$ B1 gene at position -94 ins/del ATTG with PCRRFLP method. Primer sequences are shown for each primer pair in Table 1.

DNA samples were amplified by PCR (PTC-200 thermal cycler, MJ Research, Watertown, MA, USA) with specific primers for each examined polymorphism. PCR reaction mixtures $(50 \mu \mathrm{l})$ contained $5 \mu \mathrm{l} \times 10(100 \mathrm{mM}$ Tris- $\mathrm{HCl}, \mathrm{pH} 8.8,500 \mathrm{mM} \mathrm{KCl}$, $0.8 \%$ Nonidet P-40) PCR buffer, $0,2 \mathrm{mM}$ each dNTP, 10 pmol of each primer (forward and reverse control and allele specific), $1.5 \mathrm{mM} \mathrm{MgCl}_{2}, 200 \mathrm{ng}$ of genomic DNA(Fermentas, Maryland, USA), 0.5 U Taq DNA polymerase (Fermentas, Maryland, USA) and each internal control primers.

For interleukin-6 $(-174 \mathrm{G} / \mathrm{C})$, the following PCR protocol was used: $94^{\circ} \mathrm{C}$ for $3 \mathrm{~min}$ (initial denaturation), $94^{\circ} \mathrm{C}$ for 30 $\mathrm{s}$ (denaturation), $62.6^{\circ} \mathrm{C}$ for $40 \mathrm{~s}$ (annealing), $72^{\circ} \mathrm{C}$ for $40 \mathrm{~s}$ (extension). The total number of cycles was 35 followed by a final extension of $72^{\circ} \mathrm{C}$ for $5 \mathrm{~min}$. We used NlaIII and a cleavage protocol following the manufacturer's instructions. NlaIII cleaves a restriction site at position -174 when $G$ is present, leading to fragments of 29, 176, 202, and 233 base pairs (bp) in length or $29,111,122,176$ and $202 \mathrm{bp}$ when $\mathrm{C}$ is present. In heterozygote individuals (A/C) have 42, 66, 232, 240 and 306 base pairs in length. 
Table 1. Primer sequences and reaction properties for genes

\begin{tabular}{|c|c|c|c|}
\hline Marker & Primer sequences & Annealing temperature $\left({ }^{\circ} \mathrm{C}\right)$ & Base pairs of amplicon size \\
\hline \multirow{2}{*}{ IL-6 (-174) } & 5'-GGGCTGCGATGGAGTCAGAG-3' & \multirow{2}{*}{62.6} & \multirow{2}{*}{639} \\
\hline & 5'-TCCCTCACACAGGGCTCGAC-3' & & \\
\hline \multirow{2}{*}{ IL-10 (-597) } & 5'-ATCCAAGACAACACTACTAA-3' & \multirow{2}{*}{48} & \multirow{2}{*}{412} \\
\hline & 5'-TAAATATCCTCAAAGTTCC-3' & & \\
\hline \multirow{2}{*}{ NF-kB1 (-94ATTG) } & 5'-TGGGCACAAGTCGTTTATGA-3' & \multirow{2}{*}{51.5} & \multirow{2}{*}{285} \\
\hline & 5'-CTGGAGCCGGTAGGGAAG-3' & & \\
\hline
\end{tabular}

For interleukin-10(-597A/C), the following PCR protocol was used: $94^{\circ} \mathrm{C}$ for $3 \mathrm{~min}$ (initial denaturation), $94^{\circ} \mathrm{C}$ for $30 \mathrm{~s}$ (denaturation), $48^{\circ} \mathrm{C}$ for $40 \mathrm{~s}$ (annealing), $72^{\circ} \mathrm{C}$ for $40 \mathrm{~s}$ (extension). The total number of cycles was 35 followed by a final extension of $72{ }^{\circ} \mathrm{C}$ for $5 \mathrm{~min}$. We used RsaI and a cleavage protocol following the manufacturer's instructions. RsaI cleaves a restriction site at position -597 when A is present, leading to fragments of 42,66 , 232 and 240 base pairs (bp) in length or 42, 232 and 306 bp when $\mathrm{C}$ is present. In heterozygote individuals (A/C) have 42, 66, 232, 240 and 306 base pairs in length.

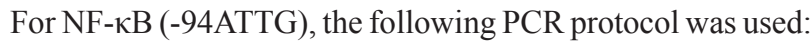
$94^{\circ} \mathrm{C}$ for $3 \mathrm{~min}$ (initial denaturation), $94^{\circ} \mathrm{C}$ for $30 \mathrm{~s}$ (denaturation), $51.5^{\circ} \mathrm{C}$ for $40 \mathrm{~s}$ (annealing), $72^{\circ} \mathrm{C}$ for $40 \mathrm{~s}$ (extension). The total number of cycles was 35 followed by a final extension of $72^{\circ} \mathrm{C}$ for $5 \mathrm{~min}$. We used PflM 1 and a cleavage protocol following the manufacturer's instructions.

The alleles were separated by $3 \%$ agarose gel electrophoresis and stained with ethidium bromide. Following electrophoresis, the PCR products were visualized under ultraviolet light.

\section{Statistical Analysis}

The chi-square test was used to test for deviation of genotype frequencies from Hardy-Weinberg equilibrium and to compare the genotype distributions among individuals with GAgP and healthy controls. Odds ratios (ORs) and 95\% confidence intervals were calculated to determine the strength of the association. A p-value of $<0.05$ was considered significant.

Statistical analysis was performed using the program SPSS 15.0 (SPSS Inc., Chicago, IL, USA). Demographic data and clinical parameters were expressed as a mean \pm standard de- viation. Genotype frequencies were tabulated by direct counting and allele frequencies were calculated from the observed number of genotypes. Chi-square $\left(\chi^{2}\right)$ analysis was used to test for deviation of allele frequencies and genotype distribution. Odds ratios (ORs) and 95\% confidence intervals (95\% CIs) were also calculated for significant associations. Kruskal-Wallis test was used to perform group comparisons. The relationship among all genotypes and chronic/aggressive periodontitis was analysis by logistic regression analysis while adjusting for potential confounding factors including age and gender. A $p$ value of $<0.05$ was considered statistically significant. The power of the analysis was completed by the utilizing data from a previous publication (19). An alpha of 0.05 was selected for calculation. The required sample size was 50 in AgP group, giving a statistical power of $80 \%$.

\section{RESULTS}

The frequencies of NF- $\mathrm{BB} 1$ and IL-10 genotypes in all groups were found in accordance with Hardy-Weinberg equilibrium ( $p>0.05)$, whereas IL-6 genotypes showed disequilibrium $(\mathrm{p}<0.05)$.

The demographic and clinical characteristics of the study groups are summarized in Table 2. When comparing the groups with the healthy controls, no statistically significant differences in age and gender could be detected.

The genotype distribution fulfilled Hardy-Weinberg criteria. The distribution of all genotypes for study genes among the study groups is presented in Table 3. Distribution of the NF-kB1 gene ins/del, del/del, ins/ins genotypes was not different among the

Table 2. Demographic and clinical characteristic of study groups

\begin{tabular}{|c|c|c|c|}
\hline & $\begin{array}{l}\text { Chronic periodontitis } \\
\qquad N=45\end{array}$ & $\begin{array}{l}\text { Aggressive periodontitis } \\
\qquad N=58\end{array}$ & $\begin{array}{l}\text { Healthy controls } \\
\qquad N=38\end{array}$ \\
\hline \multicolumn{4}{|l|}{ Age (years) } \\
\hline Mean \pm SD & $33.8 \pm 6.0$ & $29.9 \pm 5.5$ & $32.8 \pm 6.4$ \\
\hline Range & $20-46$ & 20-39 & $24-46$ \\
\hline \multicolumn{4}{|l|}{ Gender } \\
\hline Male, n (\%) & $13(28.9)$ & $26(44.8)$ & $11(28.9)$ \\
\hline Female, n (\%) & $32(71.1)$ & $32(55.2)$ & $27(71.1)$ \\
\hline $\mathrm{PD}(\mathrm{mm}$, mean $\pm \mathrm{SD})$ & $4.4 \pm 0.7$ & $5 \pm 0.8$ & $1.5 \pm 0.3$ \\
\hline $\mathrm{CAL}(\mathrm{mm}$, mean $\pm \mathrm{SD})$ & $4.8 \pm 0.7$ & $5.4 \pm 1$ & NA \\
\hline
\end{tabular}

PD - probing depth; CAL - clinical attachment level; SD - standard deviation; NA - not applicable 
study groups $(\mathrm{p}>0.05)$. Also, the relation of NF- $\kappa \mathrm{B} 1$ genotypes with IL-6 and IL-10 genotypes in patients with chronic/aggressive periodontitis subjects and healthy controls was analyzed. Among subjects with the ins/ins genotypes of NF- $\kappa B 1$ gene, the AA genotypes of IL-10 presented a higher frequency in chronic periodontitis group than in healthy controls $(p=0.023)$. No sta-

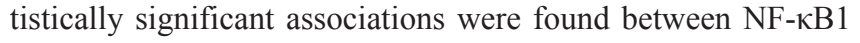
and IL-6 polymorphisms among all groups.

A statistically significant difference in genotyping frequencies between AP group and healthy controls was observed for the IL-6 gene $(p=0.002)$. The GG genotypes were associated with increased susceptibility to AP group $(\mathrm{GG} / \mathrm{GC}+\mathrm{CC}$ : $\mathrm{OR}=3.54$, 95\% CI: 1.49-8.42). No difference was found in IL-6 genotype when compared CP group with healthy controls. However, there was a significant difference in the IL-6 genotypes frequency considering all periodontitis patients $(\mathrm{CP}+\mathrm{AP}$ group) compared to controls, and the calculation of the OR revealed that patients with the GG genotype seemed to be three times susceptible to periodontitis $(\mathrm{OR}=3.54,95 \% \mathrm{CI}: 1.43-6.92)$.

With regard to the IL-10 gene polymorphism, statistically significant differences in genotyping distribution were observed between AP group and healthy controls and CP group and healthy controls. The AA genotype was overrepresented in CP and AP groups compared to healthy controls, suggesting that the carriage of the AA genotype was associated with an increased risk of periodontal disease $(\mathrm{AA} / \mathrm{AC}+\mathrm{CC}: \mathrm{OR}=9.93,95 \% \mathrm{CI}: 2.11-46.7$, $\mathrm{OR}=5.7,95 \% \mathrm{CI}: 1.22-26.89$, respectively). Regarding the IL-10 genotype, significant differences were found in all periodontitis patient ( $\mathrm{CP}+\mathrm{AP}$ groups) compared to healthy controls, and the OR increased to 7.39 (95\% CI: 1.67-32.69).

The frequency of $\mathrm{G}$ allele at -174 positions of the IL- 6 gene were higher in $\mathrm{CP}, \mathrm{AP}$ and $\mathrm{CP}+\mathrm{AP}$ groups than those of the healthy controls and these differences were significant. However, there were no significant differences in the distribution of the IL-10-A allele among all groups.

\section{DISCUSSION}

In the present study, the associations among three different gene polymorphisms (NF- $\mathrm{BB} 1, \mathrm{IL}-6$, and IL-10) in aggressive and chronic periodontitis were investigated. We demonstrated that the -592 polymorphisms in the IL-10 gene are associated with the susceptibility of $\mathrm{CP}$ and $\mathrm{AP}$ with relevant $\mathrm{OR}$ values and association of the ins/ins genotype of NF- $\mathrm{kB} 1$ gene with the AA genotypes of IL-10 observed in chronic periodontitis. Also, the

Table 3. Genotypes and alleles distribution of polymorphisms in the NF-KB (-94 ins/del), IL-6 (-174) and IL-10 (-597) genes among study groups

\begin{tabular}{|c|c|c|c|c|c|c|c|}
\hline Genotypes & All periodontitis & $\begin{array}{c}\text { Chronic } \\
\text { periodontitis }\end{array}$ & $\begin{array}{l}\text { Aggressive } \\
\text { periodontitis }\end{array}$ & Healthy controls & $\begin{array}{c}A P+C P \\
\text { vs. controls } \\
p \text {-value }\end{array}$ & $\begin{array}{l}\text { AP vs. controls } \\
p \text {-value }\end{array}$ & $\begin{array}{l}\text { CP vs. controls } \\
\text { p-value }\end{array}$ \\
\hline \multicolumn{8}{|l|}{ NF-kB1 } \\
\hline ins/ins & $33(32)$ & $14(31.1)$ & $19(63.8)$ & $9(23.7)$ & \multirow{3}{*}{ ns } & \multirow{3}{*}{ ns } & \multirow{3}{*}{ ns } \\
\hline ins/del & $62(60.2)$ & $25(55.6)$ & $37(32.8)$ & $26(68.4)$ & & & \\
\hline del/del & $8(7.8)$ & $6(13.3)$ & $2(3.4)$ & $3(9.5)$ & & & \\
\hline \multicolumn{8}{|l|}{ IL-6 } \\
\hline $\mathrm{CC}$ & $13(12.6)$ & $8(17.8)$ & $5(8.6)$ & $13(34.2)$ & \multirow{3}{*}{0.003} & \multirow{3}{*}{0.004} & \multirow{3}{*}{ ns } \\
\hline GC & $29(28.2)$ & $12(26.7)$ & $17(29.3)$ & $13(34.2)$ & & & \\
\hline GG & $61(59.2)$ & $25(55.6)$ & $36(62.1)$ & $12(31.6)$ & & & \\
\hline \multicolumn{8}{|l|}{ |L-10 } \\
\hline $\mathrm{CC}$ & $11(10.7)$ & $5(11.1)$ & $6(10.3)$ & $2(5.3)$ & \multirow{3}{*}{0.003} & \multirow{3}{*}{0.002} & \multirow{3}{*}{0.002} \\
\hline$A C$ & $62(60.2)$ & $24(35.6)$ & $38(65.5)$ & $34(89.5)$ & & & \\
\hline$A A$ & $30(29.1)$ & $16(53.3)$ & $14(24.1)$ & $2(5.3)$ & & & \\
\hline \multicolumn{8}{|c|}{ Alleles } \\
\hline \multicolumn{8}{|l|}{ NF-kB1 } \\
\hline Ins & 128 (62.1) & $53(58.8)$ & $75(64.6)$ & $44(57.8)$ & \multirow{2}{*}{ ns } & \multirow{2}{*}{ ns } & \multirow{2}{*}{ ns } \\
\hline Del & $78(37.9)$ & $37(41.2)$ & $41(35.4)$ & $32(42.2)$ & & & \\
\hline \multicolumn{8}{|l|}{ IL-6 } \\
\hline C & $55(27.3)$ & $28(31.1)$ & 27 (23.2) & $39(51.3)$ & \multirow{2}{*}{$<0.001$} & \multirow{2}{*}{0.011} & \multirow{2}{*}{$<0.001$} \\
\hline G & $151(72.7)$ & $62(68.9)$ & $89(76.8)$ & $37(48.7)$ & & & \\
\hline \multicolumn{8}{|l|}{ IL-10 } \\
\hline C & $84(40.7)$ & $34(37.7)$ & $50(43.1)$ & $38(50)$ & \multirow{2}{*}{ ns } & \multirow{2}{*}{ ns } & \multirow{2}{*}{ ns } \\
\hline$A$ & $122(59.3)$ & $56(62.3)$ & $66(56.9)$ & $38(50)$ & & & \\
\hline
\end{tabular}


results of this study indicate that IL-6 GG genotype and G allele appear to have a role in susceptibility to AP.

Human NF- $\kappa$ B1 gene plays a critical role in coordinating the immune system through its ability to regulate the transcription of a broad variety of genes implicated in the immune system including those of pro-inflammatory and anti-inflammatory cytokines (26). Also, an in vitro study suggested that IL-10 inhibits TNF-induced and LPS-induced DNA binding NF- $\kappa \mathrm{B}$ in a dose-dependent manner and specifically affects the p65/p50 heterodimer complex (28). The mechanism behind NF-kB1 in relation to disease susceptibility remains unclear although -94 del ATTG has been proven to reduce activation of NF- $\kappa \mathrm{B} 1$ transcription. A meta-analysis suggests an association between NF- $\kappa \mathrm{B} 1$-94ins/delATTG promoter polymorphism to certain autoimmune and inflammatory disease (diabetes mellitus, ulcerative colitis and psoriasis) in Asian population but not in the Caucasian population $(6,27)$. However, only one study suggested significant association of the homozygous mutation genotype del/del with the occurrence of aggressive periodontitis in a cohort of German Caucasians (7). In our study, we found no association of NF- $\mathrm{KB} 1$ polymorphism with $\mathrm{CP}$ and AP. However, as the functional interaction between NF- $\mathrm{NB}$ and other cytokines has been demonstrated, we decided to investigate whether any genotype combination among subjects of the ins/ins genotypes of NF- $\kappa \mathrm{B} 1$ gene, the AA genotypes of IL-10 presented a higher frequency in chronic periodontitis group than in healthy controls.

Our results found no association between NF- $\kappa$ B1 and IL-6 gene polymorphisms. However, in this study, IL-6 GG genotypes could not modify the risk of chronic periodontitis but increased the risk of aggressive periodontitis. Several studies have been published on whether the IL-6 polymorphism predisposes to periodontitis (29-31). However, the results of studies on the associations between these polymorphism and clinical forms of periodontitis are contradictory $(13,19,32,33)$. In a study (30), that was performed to compare the frequencies of cytokines (CD14, IL-6, TNF-alfa, IL-10, TLR-4) genotypes in patients with $\mathrm{CP}$, was found that an evident association only exists between $\mathrm{T}$ genotypes of CD14 (-260) and the GG genotype of IL-6 (-174), and the extent of periodontal disease. Similar to our findings, the study by Nibali et al. (33), which involved 224 AP patients and 231 controls, revealed that the $-174 \mathrm{G}$ allele is significantly associated with an increased risk of AP. Although there are different findings in the literature $(2,10,34)$, Fishman et al. (12) suggested that higher serum IL-6 levels were associated with the carriage of allele G for the IL-6 (-174) gene. In our study, with regard to allele distribution, $-174 \mathrm{G}$ allele significantly increased in both chronic and aggressive periodontitis.

Allelic variation in cytokine genes regulating their expression results in phenotypic differences in cytokine response $(3,35)$. The synthesis of monocyte-derived pro-inflammatory cytokines including IL-1, IL-6 and IL-8 are inhibited by IL-10 so that this cytokine down-regulates immune response (24). Therefore, the levels of IL-10 production would appear to be critical in immune regulation. Considering the pro-inflammatory and antiinflammatory profiles of IL-6 and IL-10, respectively, we evaluated the relation IL- 6 with IL-10 genotypes in study groups. No association was observed between these genotypes and the study groups. This was similar to the results of Brazil investigation, in which the TNF- $\alpha$ and IL-10 genotypes did not relate to different clinical forms or severity of periodontitis (20).
Regarding the IL-10 polymorphism, in contrast to other studies (15, 22-24), an association between allele A and either CP or AP was not observed in our study. A recent meta-analysis suggests that the IL-10 -597 An allele can provide an increased CP risk compared with the $\mathrm{C}$ allele. However, some studies are in agreement with our results that found no association between the -597 An allele and CP $(3,4,20)$. Concerning AP, similar to our findings, the existing studies suggest no association of AP with IL-10 gene polymorphism, except a weak trend in the IL-10 -597 C $>$ A polymorphism $(17,19,24,36,37)$.

Nevertheless, some limitations of our study should be mentioned. Firstly, we did not measure RNA expression or protein levels of cytokines, and thus we do not know the functional consequences of the polymorphisms of these genes in aggressive and chronic periodontitis. Secondly, we did not assess the other single nucleotide polymorphisms of these genes and the effect of haplotype combinations about IL-6, IL-10, and NFאB1 genes. A precise statement about a possible association of a genetic locus with a disease can only be made if the full haplotype information had been assessed (38).

Although ethnic factors might play a role in the variability of results in a different population, within the limitation of sample number in this study, IL-6 -174 G allele seems to be associated with $\mathrm{CP}$ and AP, but GG genotype associated with only aggressive periodontitis. On the other hand, AA genotype of IL-10 gene contributes to susceptibility to $\mathrm{CP}$ and AP and association of the ins/ins genotype of NF- $\mathrm{BB} 1$ gene with the AA genotypes of IL-10 observed in chronic periodontitis. Finally, we suggest that more extensive studies in other ethnical populations should be undertaken in order to analyze associations among these gene polymorphisms in the pathogenesis of periodontitis.

\section{Conflict of Interests}

None declared

\section{REFERENCES}

1. Yücel OO, Berker E, Gariboğlu S, Otlu H. Interleukin-11, interleukin1 beta, interleukin-12 and the pathogenesis of inflammatory periodontal diseases. J Clin Periodontol. 2008 May;35(5):365-70.

2. Moreira PR, Lima PM, Sathler KO, Imanishi SA, Costa JE, Gomes RS, et al. Interleukin-6 expression and gene polymorphism are associated with severity of periodontal disease in a sample of Brazilian individuals. Clin Exp Immunol. 2007 Apr;148(1):119-26.

3. Yamazaki K, Tabeta K, Nakajima T, Ohsawa Y, Ueki K, Itoh H, et al. Interleukin-10 gene promoter polymorphism in Japanese patients with adult and early-onset periodontitis. J Clin Periodontol. 2001 Sep;28(9):828-32.

4. Brett PM, Zygogianni P, Griffiths GS, Tomaz M, Parkar M, D'Aiuto F, et al. Functional gene polymorphisms in aggressive and chronic periodontitis. J Dent Res. 2005 Dec;84(12):1149-53.

5. Lin SC, Liu CJ, Yeh WI, Lui MT, Chang KW, Chang CS. Functional polymorphism in NFKB1 promoter is related to the risks of oral squamous cell carcinoma occurring on older male areca (betel) chewers. Cancer Lett. 2006 Nov 8;243(1):47-54.

6. Salim PH, Jobim M, Bredemeier M, Chies JA, Brenol JC, Jobim LF, et al. Interleukin-10 gene promoter and NFKB1 promoter insertion/ deletion polymorphisms in systemic sclerosis. Scand J Immunol. 2013 Feb;77(2):162-8.

7. Schulz S, Hierse L, Altermann W, Klapproth J, Zimmermann U, Reichert $\mathrm{Y}$, et al. The del/del genotype of the nuclear factor-kappaB -94ATTG polymorphism and its relation to aggressive periodontitis. J Periodontal Res. 2010 Jun;45(3):396-403.

8. Tak PP, Firestein GS. NF-kappaB: a key role in inflammatory diseases. J Clin Invest. $2001 \mathrm{Jan} ; 107(1): 7-11$. 
9. Mori N, Prager D. Activation of the interleukin-10 gene in the human T lymphoma line HuT 78: identification and characterization of NF-kappa $\mathrm{B}$ binding sites in the regulatory region of the interleukin-10 gene. Eur J Haematol. 1997 Sep;59(3):162-70.

10. Stefani FA, Viana MB, Dupim AC, Brito JA, Gomez RS, da Costa JE, et al. Expression, polymorphism and methylation pattern of interleukin-6 in periodontal tissues. Immunobiology. 2013 Jul;218(7):1012-7.

11. Komatsu Y, Tai H, Galicia JC, Shimada Y, Endo M, Akazawa K, et al. Interleukin-6 (IL-6)-373 A9T11 allele is associated with reduced susceptibility to chronic periodontitis in Japanese subjects and decreased serum IL-6 level. Tissue Antigens. 2005 Jan;65(1):110-4.

12. Fishman D, Faulds G, Jeffery R, Mohamed-Ali V, Yudkin JS, Humphries $\mathrm{S}$, et al. The effect of novel polymorphisms in the interleukin-6 (IL-6) gene on IL-6 transcription and plasma IL-6 levels, and an association with systemic-onset juvenile chronic arthritis. J Clin Invest. 1998 Oct $1 ; 102(7): 1369-76$.

13. Shao MY, Huang P, Cheng R, Hu T. Interleukin-6 polymorphisms modify the risk of periodontitis: a systematic review and meta-analysis. J Zhejiang Univ Sci B. 2009 Dec;10(12):920-7.

14. Holla LI, Fassmann A, Stejskalová A, Znojil V, Vaněk J, Vacha J. Analysis of the interleukin- 6 gene promoter polymorphisms in Czech patients with chronic periodontitis. J Periodontol. 2004 Jan;75(1):30-6.

15. Sumer AP, Kara N, Keles GC, Gunes S, Koprulu H, Bagci H. Association of interleukin-10 gene polymorphisms with severe generalized chronic periodontitis. J Periodontol. 2007 Mar;78(3):493-7.

16. Atanasovska-Stojanovska A, Trajkov D, Popovska M, Spiroski M. IL10 -1082 , IL10 -819 and IL10 -592 polymorphisms are associated with chronic periodontitis in a Macedonian population. Hum Immunol. 2012 Jul; 73(7):753-8.

17. Jaradat SM, Ababneh KT, Jaradat SA, Abbadi MS, Taha AH, Karasneh JA, et al. Association of interleukin-10 gene promoter polymorphisms with chronic and aggressive periodontitis. Oral Dis. 2012 Apr;18(3):271-9.

18. Albuquerque CM, Cortinhas AJ, Morinha FJ, Leitão JC, Viegas CA, Bastos EM. Association of the IL-10 polymorphisms and periodontitis: a meta-analysis. Mol Biol Rep. 2012 Oct;39(10):9319-29.

19. Gonzales JR, Michel J, Diete A, Herrmann JM, Bödeker RH, Meyle J. Analysis of genetic polymorphisms at the interleukin-10 loci in aggressive and chronic periodontitis. J Clin Periodontol. 2002 Sep;29(9):816-22.

20. Moreira PR, Costa JE, Gomez RS, Gollob KJ, Dutra WO. TNFA and IL10 gene polymorphisms are not associated with periodontitis in Brazilians. Open Dent J. 2009 Sep 7;3:184-90.

21. Cullinan MP, Westerman B, Hamlet SM, Palmer JE, Faddy MJ, Seymour GJ, et al. Progression of periodontal disease and interleukin-10 gene polymorphism. J Periodontal Res. 2008 Jun;43(3):328-33.

22. Scarel-Caminaga RM, Trevilatto PC, Souza AP, Brito RB, Camargo LE, Line SR. Interleukin 10 gene promoter polymorphisms are associated with chronic periodontitis. J Clin Periodontol. 2004 Jun;31(6):443-8.

23. Claudino M, Trombone AP, Cardoso CR, Ferreira SB Jr, Martins W Jr, Assis GF, et al. The broad effects of the functional IL-10 promoter-592 polymorphism: modulation of IL-10, TIMP-3, and OPG expression and their association with periodontal disease outcome. J Leukoc Biol. 2008 Dec;84(6):1565-73.

24. Hu KF, Huang KC, Ho YP, Lin YC, Ho KY, Wu YM, et al. Interleukin-10 $(-592 \mathrm{C} / \mathrm{A})$ and interleukin-12B $(+16974 \mathrm{~A} / \mathrm{C})$ gene polymorphisms and the interleukin-10 ATA haplotype are associated with periodontitis in a Taiwanese population. J Periodontal Res. 2009 Jun;44(3):378-85.

25. Armitage GC. Development of a classification system for periodontal diseases and conditions. Ann Periodontol. 1999 Dec;4(1):1-6.

26. Löe $H$. The Gingival Index, the Plaque Index and the Retention Index Systems. J Periodontol. 1967 Nov-Dec;38(6):Suppl:610-6.

27. Zou YF, Wang F, Feng XL, Tao JH, Zhu JM, Pan FM, et al. Association of NFKB1 -94ins/delATTG promoter polymorphism with susceptibility to autoimmune and inflammatory diseases: a meta-analysis. Tissue Antigens. 2011 Jan;77(1):9-17.

28. Schottelius AJ, Mayo MW, Sartor RB, Baldwin AS Jr. Interleukin-10 signaling blocks inhibitor of kappaB kinase activity and nuclear factor kappaB DNA binding. J Biol Chem. 1999 Nov 5;274(45):31868-74.

29. Trindade SC, Olczak T, Gomes-Filho IS, de Moura-Costa LF, Vale VC, Galdino-Neto M, et al. Porphyromonas gingivalis HmuY-induced production of interleukin- 6 and IL-6 polymorphism in chronic periodontitis. $\mathrm{J}$ Periodontol. 2013 May;84(5):650-5.

30. Tervonen T, Raunio T, Knuuttila M, Karttunen R. Polymorphisms in the CD14 and IL-6 genes associated with periodontal disease. J Clin Periodontol. 2007 May;34(5):377-83.

31. Trevilatto PC, Scarel-Caminaga RM, de Brito RB Jr, de Souza AP, Line SR. Polymorphism at position -174 of IL- 6 gene is associated with susceptibility to chronic periodontitis in a Caucasian Brazilian population. J Clin Periodontol. 2003 May;30(5):438-42.

32. Nibali L, D'Aiuto F, Donos N, Griffiths GS, Parkar M, Tonetti MS, et al. Association between periodontitis and common variants in the promoter of the interleukin-6 gene. Cytokine. 2009 Jan;45(1):50-4.

33. Nibali L, Griffiths GS, Donos N, Parkar M, D'Aiuto F, Tonetti MS, et al. Association between interleukin-6 promoter haplotypes and aggressive periodontitis. J Clin Periodontol. 2008 Mar;35(3):193-8.

34. D'Aiuto F, Parkar M, Brett PM, Ready D, Tonetti MS. Gene polymorphisms in pro-inflammatory cytokines are associated with systemic inflammation in patients with severe periodontal infections. Cytokine. 2004 Oct 7;28(1):29-34.

35. Bidwell J, Keen L, Gallagher G, Kimberly R, Huizinga T, McDermott MF, et al. Cytokine gene polymorphism in human disease: on-line databases. Genes Immun. 1999 Sep;1(1):3-19.

36. Reichert S, Machulla HK, Klapproth J, Zimmermann U, Reichert Y, Gläser $\mathrm{CH}$, et al. The interleukin-10 promoter haplotype ATA is a putative risk factor for aggressive periodontitis. J Periodontal Res. 2008 Feb;43(1):407.

37. Zhong Q, Ding C, Wang M, Sun Y, Xu Y. Interleukin-10 gene polymorphisms and chronic/aggressive periodontitis susceptibility: a meta-analysis based on 14 case-control studies. Cytokine. 2012 Oct;60(1):47-54.

38. Schäfer AS, Jepsen S, Loos BG. Periodontal genetics: a decade of genetic association studies mandates better study designs. J Clin Periodontol. $2011 \mathrm{Feb} ; 38(2): 103-7$. 